\title{
African Neo-Pentecostal capitalism through the lens of Ujamaa
}

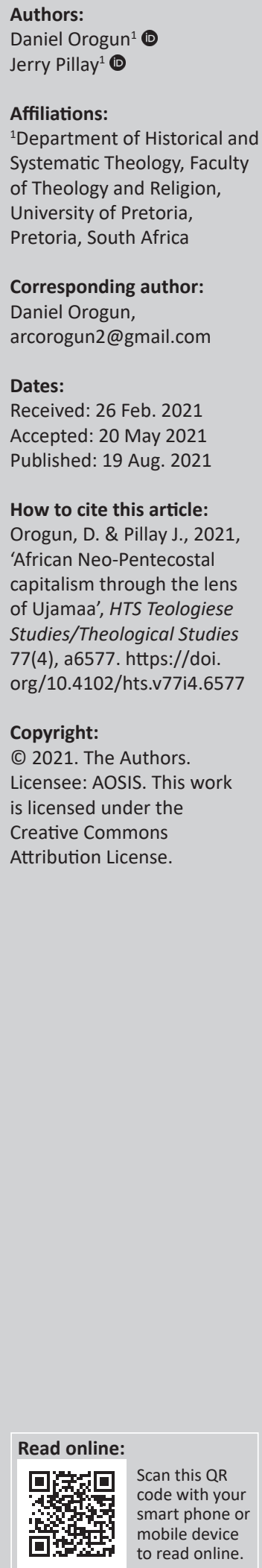

This article engaged in critical analyses of the capitalistic nature of the practices of African Neo-Pentecostal leaders with a focus on a few but most popular Nigerian and South African Neo-Pentecostal leaders. Using Julius Nyerere's African moral philosophy called Ujamaa, the article viewed and critiqued the narratives with an emphasis on how antithetical such practices are to the communitarian nature of African society which provides for people-centred servant leadership. Progressively, the article discovered that such capitalistic practices promote manipulative, exploitative and inhuman culture and therefore engenders gross socio-moral and socio-economic abuse of the rights and privileges of millions of Church adherents. It further deduced that amongst others, lack of love towards the adherents and surrounding communities is at the heart of such bankrupt practices and therefore recommended the three principles and three factors of Ujamaa's philosophy as essential values needed for the transformation of the Neo-Pentecostal religious organisations or nations. It is the conclusive remark of this article that every leader needs to adopt Ujamaa's philosophy as a basic leadership requirement for communitarian and people-centred service to humanity.

Contribution: Aligning with HTS Teologiese Studies/Theological Studies focus and scope, this article contributed to an interdisciplinary religious aspect of research as it brought forward the interplay of African Moral Philosophy and African Pentecostal Theology aimed at discovering pathways to improve the African Christian leaders' socio-moral and socio-economic services to adherents and African communities at large.

Keywords: capitalism; community; leadership; prosperity gospel; socio-moral; socioeconomic; theology; African Neo-Pentecostalism; Ujamaa and African moral philosophy.

\section{Introduction}

Pastoral duties are likely beyond the daily routine of liturgical and sacramental responsibilities provided by the clergies to the congregants. Christian leadership ought to provide total wellbeing services to congregants and surrounding communities alike. A good example can be seen in the prayers and wishes of Elder John for Gaius in 3 John 1:2. Elder John's prayers suggested that the total well-being of followers can be part of a leader's oversight function. In other words, to assert that the Church leadership exists for the total well-being of the adherents in spirit, soul and body may not be incorrect. Thus, the social upliftment of any community is not an exclusive function of the political leaders, but also the Christian leaders. Correspondingly, to achieve people-centred social and spiritual services by Neo-Pentecostal leaders, a great deal of sociomoral obligations and expressions capable of providing spiritual, socio-moral and socio-economic benefits to the adherents are required. Therefore, on the account of the detailed scholarly discussion presented in support of the principles, factors and relevance of Ujamaa in the section titled 'The Ujamaa principles, factors, their interplay with theology and the essence for Africa,' this article argues that Ujamaa can be adopted as a socio-moral template for people-centred social and spiritual servant leadership practices. Likewise, Ujamaa can be utilised to critique the practices of African Neo-Pentecostal leaders. This is the core of this article to evaluate the African NeoPentecostal leaders' capitalistic activities through the lens of Ujamaa. To achieve this, the article will systematically build its argument in sections: The 'Introduction' opens the discussion with abstract and introduction, respectively. The section titled 'The problem' will narrate the eruption of Neo-Pentecostal capitalism with its abounding problems. The section 'Examples of NeoPentecostal capitalistic activities' will articulate various examples of such capitalistic practices. Correspondingly, Ujamaa principles and factors, their interplay with theology and their essence for Africa will be delineated in the section titled 'The Ujamaa principles, factors, their interplay with theology and the essence for Africa'. Additionally, the section 'Contrast and analyses of Neo-

Note: Special Collection: Theology, Economy and Environment: Social, Cultural and Biotic Influences on Religious Communities, subedited by Jerry Pillay (University of Pretoria). 
Pentecostal capitalism in the eye of Ujamaa' will place African Neo-Pentecostal capitalism under the lens of Ujamaa principles and factors to view the contrast. In the end, the article will make conclusive remarks based on the analyses.

As a concluding remark in this introduction, the authors would like to put it on record that many studies on this topic would normally work with the perspective of Ubuntu in terms of looking at African concepts. Likewise, there is a strong possibility that other related studies would have used Jesus' model of servant leadership to address trending sociomoral issues amongst the African Christian leaders. However, the task of this article is to take a different African Philosophical model called Ujamaa to critique African NeoPentecostalism. The task is further not to work with the normal principles of Jesus's model of servant leadership which is understood and appreciated by the authors. This article seeks to explore the philosophy of Ujamaa in terms of how it can be used to address the issue of Pentecostal capitalism. Worthy of note is that every model propagated including Ujamaa may not be perfect, but the goal of this article is to explore and see what can be learnt from the model in terms of our Christian concept. Thus, the focus of this article is the principles of Ujamaa and not the person of Julius Nyerere. Frailties are common to all humans, notwithstanding their contributions to socio-moral and leadership development cannot be waived off. This article will now narrate the problem in the following section.

\section{The problem}

As Maxwell views it, 'everything rises and falls on leadership' (Maxwell 2007:267). The statement is not only applicable to secular organisations; the socio-moral correctness and successful running of any religious organisation depend on the role of the leaders. Invariably, followers look up to leaders for spiritual, moral and social guidance. Unfortunately, it appears that some African Neo-Pentecostal ${ }^{1}$ leaders have not lived up to expectation in their socio-moral responsibilities. The ideal Pentecostal theology before the late 17th century provides for moral sanity and integrity such that leaders carry out their duties faithfully regardless of material reward. Thus, serving humanity was at the centre. Synan (2019) in his historical analysis showed that the goals of the founding fathers of Pentecostalism were not acquisitiveness and profitmaking for self-aggrandisement, rather, serving humanity was at the centre. Synan (2019) further mentioned that they were overwhelmingly Arminian in their basic theology and were strongly perfectionistic in their spirituality and lifestyle. ${ }^{2}$ Subsequently, the fundamentals of holiness, uprightness and morally acceptable theology were replaced by the NeoPentecostal capitalistic style. This style has since then taken

1.Pentecostal capitalism is the adoption of one or more forms of capitalism systems as the financial and administrative pattern upon which Pentecostal practice is structured. It uses of capitalists' patterns in missions, policy formation, staffing, funding, ownership, and 'leader-follower relationship' so that it favours the leaders, and few individuals at the expense of the majority. It is the adoption of the philosophy of free-market enterprise to run the church. It is a practice that supports individualism rather than collectivism in the Pentecostal denominations.

2.The founding fathers' culture and 1960s movement led by Dennis Bennett, Charles Fox Parham and William J. Seymour are available at: http://digitalcommons.liberty.edu/cgm_missions/7

https://core.ac.uk/download/pdf/58820129.pdf over the phase of many Neo-Pentecostal ministries across the globe (See Quayesi-Amakye 2016:77). ${ }^{3}$

Indeed, the ideal culture and protocol had been superimposed by the enterprising gospel. Halverson could not agree less with an apt description of the chain of retrogressive change in the global church when he alleged that 'the church was once a fellowship of men and women centring on the living Christ. Then the church moved to Greece as a philosophy. Then it moved to Rome where it became an institution. Next, it moved to Europe, where it became a culture. And finally, it moved to America where it became an enterprise' (Halverson n.d.). Sadly, the same American enterprise ideology was passed on to many African Neo-Pentecostals. Little wonder, some African Neo-Pentecostal preachers joined the league of the richest preachers in the world (see Italoye 2019). Unfortunately, the prevailing poverty in Africa made NeoPentecostal capitalism via prosperity gospel easily acceptable to the adherents (see Okosun 2018:89; cf Kalu 2008). With such leverage on Africa's economic predicaments, prosperity theology became the signature of the contemporary NeoPentecostals in Africa.

Furthermore, the prosperity gospel takes the form of secular and capitalistic business activities. Consequently, profitmaking drives the motive of many Neo-Pentecostal preachers, hence they can be regarded as Neo-Pentecostal capitalists. Whilst various economic scholars have their definitions, this article sustains the definition of Pettinger (2012:1), who classified capitalism into Monopoly, Turbo, Responsible, Popular, Crony and State capitalism. Based on Pettinger's definitions, ${ }^{4}$ Turbo or Casino and Monopoly capitalistic practices are the closest to Neo-Pentecostal capitalistic practices. As earlier stated in footnote, ${ }^{1}$ looking at the two words Neo-Pentecostalism and Capitalism as one compound word in the context of Neo-Pentecostal practices, it may be safe by inference to describe Neo-Pentecostal capitalism as the use of capitalists' business ideology in missional policies and practices in favour of the pastoral venture capitalists or religious business owners. Concomitantly, Neo-Pentecostal capitalism is bringing down the cross and replacing it with the charismatic leaders' business interest. Consequently, the existence of Neo-Pentecostal capitalism leads to the commodification of the gospel and subsequently socio-moral and socio-economic damages against over 107 million African Pentecostal adherents. ${ }^{5}$ Surely, such catastrophic practices with negative impacts on large African demographics require a critical view with an African moral philosophy like Ujamaa. In the following section, we attempt to show how NeoPentecostal capitalistic tendencies can be seen in some of its church leaders.

3.Neo-Pentecostalism emerged in the 1950 s and 1960 s, but those referred to here are the newer African versions of the 1980s to date.

4.Pettinger (2012:1) asserts that monopoly capitalism is a form of capitalism where the control of the market is in the hand of private individuals. In an oligopoly market structure, there are a few interdependent firms which dominate the market. $H$ defines Turbo capitalism as an unregulated labour market, where it is easy to hire and fefines Turbo cand very limited regulation about wark capitalism creates a wider gap between the financially weak and the wealthy in society.

5.Pew Research Centre (2006) reported that there are over $12 \%$ of Africa's population representing 107 million Pentecostals across Africa. See details at https://www. pewforum.org/2006/10/05/overview-pentecostalism-in-africa/ 


\section{Examples of Neo-Pentecostal capitalistic activities}

Agreeably, not all Neo-Pentecostal Christian leaders are involved in non-people centred capitalistic practices. Thus, this article holds no bias against any Neo-Pentecostal leader or group. Rather, the authors opine that not all NeoPentecostal leaders are culpable. Whilst there are many examples of people-centred servant leaders amongst African Neo-Pentecostals, the pieces of information below allegedly suggest that some African Neo-Pentecostal leaders are agents of capitalism. Although there are many alleged cases reported, ${ }^{6}$ this section will only accommodate a few. ${ }^{7}$ Additionally, despite various YouTube video links provided as proof, the authors still hold the examples provided as alleged information, with the hope that the final decisions of the courts of law, anti-graft agencies and civil right commissions investigating the matters will put to rest the doubts on the authenticity of the reports. We will now attempt to lay out the examples in the following subsections.

\section{Oristejafor and Oyakhilome}

Nairaland Forum (2010) alleged that Christ Embassy Pastor, Chris Oyakhilome was involved in a \$35000 000 money laundering scam and was invited to the anti-graft agency called the Economic and Financial Crime Commission (EFCC). ${ }^{8}$ The money was allegedly stolen from Sheraton Hotel in Lagos by a staff who happens to be a member of Oyakhilome's church. The money was given to Oyakhilome but the management of the Hotel raised an alarm and reported the case to EFCC. Correspondingly, The Nigerian Voice (2015) alleged that an aircraft belonging to Ayo Oritsejafor, the former president of the Pentecostal Fellowship of Nigeria (PFN), was caught loaded with \$9.3000 000 along with three men in South Africa whilst trying to purchase ammunition (cf Hart 2015:1). ${ }^{9}$ In response to EFCC, Oritsejafor claimed that some members of his church formed a committee, worked directly with his wife and presented the said private jet to him as a gift (cf Hart 2015:1). Reacting to the money laundering and arms trafficking scandal, the former governor of Benue state, Senator George Akume in a press conference asked - how will Oritsejafor explain his involvement with people engaged in international arms trafficking? He asked further if the three passengers arrested along with the aircraft in South Africa were on a pastoral visit to preach the gospel of Jesus Christ (The Nigerian Voice 2015). Theologically, no scripture validates arms trafficking, money laundering or stealing to promote missional assignment. At the very least,

6.The article does not claim to be the source of all information in cases where original names of clergies were used. All information were allegedly presented from initia media published sources in the public domain.

7.This article is an offshoot of a PhD thesis. More literature and media investigation reports and examples can be obtained in the full thesis. See details in 'Agencies of Capitalism: Evaluating Nigerian Pentecostalism using African Moral Philosophies', submitted in the year 2020 to the Faculty of Theology, University of Pretoria.

8.See further information at https://www.thenigerianvoice.com/lifestyle/39706/ pastor-chris-oyakhilome-in-a-35-million-money-laundering-sc.html. Also see https://semasir.wordpress.com/2012/12/22/pastor-chris-oyakhilomes-financialhttps://semasir.wordpress.com/

9.See Hart's report on https://www.legit.ng/290917-private-jet-seized-sa-9-3mlnarms-smuggling-money-linked-can-president-report.html owners were consulted before any property was used. (See Mt 21:1). If any staff of a company steal to promote missional work or if the aircraft purchased for the man of God becomes arms trafficking cargo carrier, then his ministerial ethics stands questionable. Indeed, money laundering and arms trafficking, if it is true, suggest that both Oyakhilome and Oritsejafor are unethical venture capitalists.

\section{Prophet Joshua Iginla, Sheperd Bushiri and Alpha Lukau}

In Charlse (2019) Highstreet online journal, viewed by over 1.4 million people, he alleged that a commercial healing pool called Bethesda was built by a South African and Nigerian based prophet called Joshua Iginla. Charlse (2019) alleged that Iginla claimed that the pool has healing powers to cure diseases including human immunodeficiency virus and acquired immunodeficiency syndrome (HIV and AIDS) and Ebola and therefore charges the members a fee of N50 000 per person for a holy bath. Also, members who cannot afford N50 000 are encouraged to pay N10 000 and fetch a bottle of water from the pool to get healed miraculously (Charlse 2019). This indeed is a venture capitalist's business activity. Iginla invested in a swimming pool that yields high returns via sales of miracles and healings. ${ }^{10}$ Viewing this scenario theologically, Iginla's miracle pool has a reference in John 9:1-11, however, there was nothing commercial nor capitalistic between Jesus the healer and the blind man who washed his eyes in the pool of Siloam. More interestingly, whilst Iginla allegedly collects money from adherents for a miracle bath in his pool, Jesus never demanded money or a bath from the paralytic at the pool of Bethesda, he only commanded the man to take his bed and walk (See Jn 5:2-9). So, Jesus's miracle was not at the instance of the pool bath, but by prayers or declaration. Thus, there is no theological authenticity for Iginla's capitalistic and commercial miracle pool bath.

Congruently, Chabalala (2017) alleged in the Independence Online journal that Bushiri ${ }^{11}$ in South Africa engages in various profit ventures by extorting his members. Chabalala (2017) stated that during Christmas break, members took their 13th-month cheques and paid R25 000 to sit on a high table with Bushiri at the church's gala-night. This was done with a promise from Bushiri that all their problems will be solved spiritually if they sit with him at the gala night. This is a pure strategy of extortion; it is Neo-Pentecostal capitalism. Contrarily, the New Testament texts showed that Jesus sat with many people and ate on different occasions without commercialising the meal table or the feast (See Mt 9:9-17, Lk 6:1-5; 7:36-50, Jn 2:1-10, Lk 24:41-48). These scriptures show that Jesus's servant leadership was not about exploiting the people as against the alleged report against Bushiri.

\footnotetext{
10.The following video links further buttress the claims:

https://www.facebook.com/458203548307281/videos/594137971322675 https://www.youtube.com/watch?v=9lveozsaqku
}

https://www.facebook.com/458203548307281/videos/594137971322675

11. Bushiri is currently standing trial for the alleged charges. See eNews Channel Africa (eNCA) report at https://www.youtube.com/watch?v=DBiT-j4KUOw. Also see South African Broadcasting Corporation (SABC) News at https://www.youtube. $\mathrm{com} /$ watch?v=3UtSalr-9vg. 
Correspondingly, Cilliers (2019) alleged that Lukau pays about R3.5 million to his cronies to fake miracle during his services. ${ }^{12}$ On one occasion, he staged the raising of the dead and got several people out of wheelchairs. Thus, it is logical to allege that if he spends that much to stage-manage miracles, his gullible clients will believe more in his miraculous powers and invest more millions of Rands anytime he calls for prophetic or healing seeds. Theologically, raising the dead can be cited in both Old and New Testaments; however, none was alleged to have been stage-managed on money terms. Elijah raised the widow of Zarephath's son (1 Ki 17:17-24). Elisha raised the Shunammite woman's son (2 Ki 4:18-37). Jesus raised the widow of Nain's son (Lk 7:11-17). Tabitha in Acts 9:36-43 was raised by Peter. However, allegations and money scandals were far from these miracles. Thus, these allegations against Alpha Lukau, the court cases and the outcry of the family of the resurrected man who later died mysteriously as evidenced in footnote (13), showed that certain commercial and capitalistic activities may be ongoing in the accused clergy's ministry.

\section{Matthew Ashimolowo and Funke Adejumo}

The allegations of fraudulent and manipulative fundraising styles against Ashimolowo and Adejumo are good examples. Odunayo (2018) ${ }^{13}$ reported one of Ashimolowo's fund-raising gimmicks where he told each congregant to sow a seed of $\$ 1000$ per number of years of the giver. In other words, an individual will have to sow thousands of dollars according to the number of his or her years on earth. Also, Ijeoma (2018) reviewed at least 20 video clips, where Adejumo demanded seeds from the congregants including demands for $\$ 1000$. In one of the videos, ${ }^{14}$ Funke told mothers to sow $\$ 1000$ seeds to secure the virginity of their daughters until they are married. Theologically, whilst there may be no direct scriptural link to Ashimolowo's \$1000 seed collection, there are various scriptures on virginity discussed in the context of purity, marriage and relationship with Christ (See Lv 21:13, Mt 25:1-13, 2 Cor 11:2, Rv 14:4). In all, none represents the commercialisation of virginity. Thus, the commonest interpretation of Ashimolowo and Funke Adejumo's alleged practices will be the exploitation of church adherents using capitalistic strategies.

\section{Bishop Olowonla ${ }^{15}$}

Ogar (2017) reported that Olowonla started floating an airline in the year 2012. The investigation of Sahara Reporters (2012) showed that Olowonla sits as the Chairman of the Board of

12.On Alpha Lukau, see media alleged report by Sikhupa Mlotshwa at https://www. sowetanlive.co.za/opinion/columnists/2019-03-13-false-miracles-leave-disabled people-at-the-mercy-of-dubious-prophets/. Additionally, see SABC News reported at https://www.youtube.com/watch?v=jGJfzqD1xGc

13.Odunayo's report came along with a video clip. Also, Pastor Adelaja of the Embassy of God Church in Ukraine condemned the act in another video. See https://www. youtube.com/watch?v=NuguwO_HBLc

14.See Youtube video links of $\$ 1000$ dollar seed raised by Adejuwon: 15, July 2018, https://www.youtube.com/watch?v=pWKeK1fQRe4 (Virginity Seed) 12 July 2018 https://www.youtube.com/watch?v=chjNqXOCXeE (Virginity Seed) 28, October 2017 https://www.youtube.com/watch?v=pdukB32v67k (Seed against husbands' death)

15.Olowonla is a pseudo name used for ethical reasons. the airline. Whilst the interviews with FOPSA and JOPSA ${ }^{16}$ revealed that the private jets were purchased for missionary works of the church across the globe, Sahara Reporters (2012) obtained insider information that the cost of maintenance and parking, staff salary (pilots inclusive), escalation of aviation fuel price and landing fees led to the sale of two of Olowonla's jets. But, when buyers scarcely surfaced, Olowonla made floating an airline an alternative. With the reports of FOPSA and JOPSA (see Daniel 2021:320-333, 334-342), the conversion of the private jets purchased with congregational offerings is tantamount to an unethical business venture. Thus, Olowonla may be regarded as an unethical venture capitalist via larceny and criminal conversion.

Also, the profiteering nature of the unaffordable schools belonging to Olowonla's church shows that he has the tendencies to be a venture capitalist. FOPSA and JOPSA ${ }^{17}$ maintained that the funds that bankrolled the schools were raised from the congregants; unfortunately, average members cannot afford the schools for their children. Likewise, Sahara Reporters (2012) alleged that the secondary schools' fees range from approximately $\$ 2500$ to $\$ 3000$ per annum. Besides, the Church's University charges approximately $\$ 3500$ per session for a degree programme (Sahara Reporters 2012) As a situational review, for a country where an average Nigerian survives on about $\$ 2$ or less daily, these fees raise the question of affordability. Consequently, the conversion of such unaffordable schools to personal business shows that the schools are not people-centred, but they are part of the business conglomerates of Bishop Olowonla and his family.

Furthermore, Olowonla emphasises prosperity beyond measure. One of the biggest gatherings where giving is overemphasised is the annual Shiloh programme. From all over the world, people gather in hundreds of thousands for a week and constantly indoctrinated to give and make 'Shiloh covenant sacrifice'. These include donations of houses as seeds, cars, landed properties, local and foreign currencies, etc. Sahara Reporters (2012) alleged that Olowonla is unapologetic about the materialistic tinge to his prosperity gospel as he described his prosperity-centric teachings as 'covenant software' usable to access God's goldmine (Sahara Reporters 2012). Additionally, the simplest form of venture capitalism practised by Bishop Olowonla is the commercialisation and deification of prosperity objects. Objects such as anointing oil and handkerchiefs are sold as elements that carry the anointing after prayers are offered upon them. Salinas (2015:12) reported that Olowonla sells olive oil and holy mantles to the congregants for wealth and health benefits. Additionally, Salinas (2015:14) alleged that white handkerchiefs are referred to as mantles that have been prayed over and are believed to be so powerful that they can meet all congregants' needs. Some members hang them at the entrance of their offices or shops to attract

16.The full interviews of FOPSA and JOPSA are available in Daniel Orogun's PhD thesis, pp. 320-333 and 334-342, respectively.

17.Ibid 
customers and some on their doorpost to drive away demons (Salinas 2015:14).

Consequently, there are two questionable issues in these practices. Firstly, buying those elements from the church brings the preacher's motives into question. Secondly, ascribing some sort of spiritual power to such elements for financial breakthrough confers a level of marketing on the oil and other objects sold by the church. More importantly, in the African context, it confers idolatry and deification upon the entire practice. Ultimately, the theological question will be - where were such sales done by Christ as a way of empowering people financially in the New Testament? Contrarily, Jesus drove buyers and sellers out of the temple to protect his father's house from desecration (see Mt 21:12). This is a clear indication that Olowonla is possibly a profiteering venture capitalist deserving to be addressed as an agent of capitalism in the pulpit. In summary, with a few exceptions, many Neo-Pentecostal leaders operate in a common theological space that is exploitative, profit-oriented and not people-centred. We will now discuss Ujamaa philosophy below.

\section{The Ujamaa principles, factors, their interplay with theology and the essence for Africa}

Ujamaa is a Swahili word that means familyhood. It was chosen by Julius Nyerere to describe the kind of socialist society Tanzania desires to establish (Gbadegesin 2020:50). The discussion around Ujamaa centres on Nyerere's philosophy on various issues. Firstly, it is important to establish that Nyerere was a Christian who showed concerns on the role of the church in socio-economic and socio-political matters of the state and the welfare of the masses (Listowell 1965:183, 196). Similarly, Giblin (1992:40) opined that Nyerere acknowledged the deeply human and indeed religious aspirations of the people; he weaved the spiritual with the material essence via socialism which is the core of Ujamaa. As a propagator of African socialism, Nyerere emphasised that if a person's religion involves human sacrifice or demands exploitation of human beings, such religion is unacceptable in an Ujamaa oriented society (See Mesaki \& Malipula 2011:95). This is Nyerere's most punchy ideology against Neo-Pentecostal capitalism; exploitation of fellow human beings is forbidden. This is a fundamental philosophy. Fortunately, the Tanzanian churches seem to be receptive to Nyerere's ideology. According to Mesaki and Malipula (2011:79-98), the communiqué released in 1968 by the Roman Catholic Church of Tanzania agreed with the 'Arusha Declaration'. ${ }^{18}$ The church leadership found the true practical principles of human living in the declaration. Thus, Mesaki and Malipula (2011) declared that:

18.The Arusha Declaration is the new Tanzania resolution and constitutional document written for the Tanganyika African National Union (TANU) by Julius Nyerere on the 5th of February 1967. The Church leadership accepted and commended the agreement of the policy with the true spirit of Christ and the Church. See details at https://www.marxists.org/subject/africa/nyerere/1967/arusha-declaration.htm or https://disa.ukzn.ac.za/sites/default/files/pdf_files/Acn2967.0001.9976.000.02 9.1967.4.pdf
$[W]$ e can see very well how closely it agrees with the true spirit of Christ and the church, which is a spirit of brotherhood, of sharing, of service and hard work. (p. 97)

Indeed, the church accepts Ujamaa as being consistent with Christian beliefs of justice and equality.

Additionally, despite his educational qualifications, all Nyerere wanted were answers to such questions as to why his country was not free and why there was a colonial administration (J. Listowell 1965:208). He wanted the liberation of his people from socio-economic oppression imposed by the colonial capitalists and their allies called the African bourgeoisie. Nyerere lived out that conferment as he acted as a guiding spirit in all socio-economic and political life of the society. He was a man given to seeing an ideal state where moral and civic principles provide the environment for all peoples' well-being.

Nyerere was born under colonial suppression where a threeway social stratification was the order of the day; whites enjoying first-class rights and privileges, Asians rated as a second class with their equivalent benefits whilst the Africans were treated as third-class citizens. Denying Africans equal access and the right to vote by the Europeans stirred up a passion to see this white supremacy come to an end. Subsequently, Ujamaa emerged from the desire to end the oppression of the white supremacists. The underlining principles of Ujamaa are not only applicable to end the foreign colonialists' socio-moral abnormalities, but also the unethical activities of post-colonial African bourgeoisie which include political and religious leaders. It is on this premise that Ujamaa becomes a strong moral modicum to critique African Neo-Pentecostal bourgeoisies who exploit, manipulate and convert public (adherents) properties to personal business ventures.

Ujamaa is predicated on a higher value for communitarianism where all exists for one and one for all. This way, oppression, suppression, exploitation, injustice and inequality can be adequately addressed. To achieve this, Nyerere gave principles and factors. Gbadegesin (2020:52-54) listed the principles as 'Equality, Freedom and Unity' and the factors as 'Mutual respect, Common ownership of property and Work'. On equality, everybody is equal in society irrespective of his or her position or responsibility. For Nyerere, even a chief is recognised only as first amongst equals in terms of his relationship with the people. Unfortunately, this African modicum experienced a setback with the coming of colonialism as Kings and Chiefs acquired authority that did not belong to them according to African tradition. Originally, equality makes all people voluntarily share rights and duties of the society as a requirement of social life (Gbadegesin 2020:51; cf Nyerere 1966:8). Furthermore, Gbadegesin (2020) argued that equality does not deny the fact that an age difference and hierarchical ordering exist. Rather, it underscores the fact that within the same age grade, the equality of the members is the working basis for dealing with them. Most importantly, those in the seat of higher authority 
are held by certain socio-ethical modicum, they are placed under effective checks and balances in the unwritten constitutions of African societies.

On the factors: love, sharing and work, love is instructive in building a common society without any dispute on its importance. As individuals are loved by parents from birth, Nyerere stated that such action should grow into a community culture, this will address the selfish nature of the spirit of individualism in society. For Nyerere, the love attitude must be viewed such that everyone understands that they fall and rise together. Everyone must understand that 'I exist because there is we' (Gbadegesin 2020:53-54). The sharing factor entails joint ownership of property amongst the family members; it is an expression of the solidarity that exists between them. By implication, no member of the family goes short of food or shelter so that personal property may be acquired by another member. Each member has the right to a share of the family property as well as an expectation of a share in the private property of relatives. The property of one potentially belongs to all in a family sense; there is no room for accumulation beyond needed private appropriation. Additionally, whatever has been accumulated stands to be shared as needs may arise because needs take precedence over luxuries. Nkafu (1999) succinctly puts it thus:

$[A]$ frican socialism, whose true realisation implies sharing and distribution of goods amongst all, consists in trust of belonging to a community and this is the total responsibility of the community towards its members. (p. 52)

However, this does not create room for laziness amongst the people, which is why Nyerere added the factor of work for everyone.

On education, using the Ujamaa principles and factors, Nyerere decided to provide an education system that has been 'serving the fatherland at heart', a system made available to all and not just a few. Thus, Nyerere (1968b:45) considers education, not as a privilege of the few but the right of all. In the account of Gbadegesin (2020:66), Nyerere's Ujamaa on education demands that education curriculum should at every point emphasise self-reliance and virtue. The merit and manual of work should be the focus and from primary school to college, every student should be made to understand the need for work and self-reliance. Additionally, the educational system must emphasise cooperation and finally, it must foster social goals of communitarianism. So, using the instruments of the three principles and factors, Ujamaa carries the ideal socio-moral and socio-political weight and has what it takes to build a socio-moral and socio-economic society enjoyable by all of humanity.

As the last point in this section, it is imperative to mention that the principles and factors of Ujamaa are not in contrast with theology. The principles and factors namely, Equality, Freedom, Unity, Love, Sharing and Work are not only interconnected but they are also in alignment with scriptures. Deuteronomy 10:17 pictures the character of God as one who takes no bribe and shows no partiality. Proverbs 22:2 shows that the character of God via creation is devoid of inequality; both the rich and the poor have the same creation advantage under God. The theological position of Romans 2:11 further reveals that favouritism has no approval amongst the brethren. Also, James 2:9 outrightly opines that inequality or favouritism is condemnable. Besides, in the Christological discussion of Paul in Galatians 3:26-29, association with Christ makes all associated beings equal. Thus, when humans are baptised into Christ, their status, gender, race or colour as Jews or Gentiles, slaves or free humans, rich or poor become irrelevant; they all become equal. Correspondingly, this equality is fostered by the Love of Christ and unity amongst brethren (see Jn 3:16, Col 3:10-11, Lv 19:33-34, Ja 2:8-9, Mk 12:31). As such, the people enjoy freedom from the bondage and cruelty of inequality, disunity and racial or colour-based hatred. Additionally, Proverbs 12:24 bears witness that putting one's hand to work ensures a great future but whoever does not appreciate work is lazy. Also, Proverbs 12:11 suggests succinctly that work encourages abundance and productivity. In the theological rhetoric of Psalms (90:17) humans' handwork were blessed. Concomitantly, Ephesians 4:28 emphasised that the antidote to stealing is work. Invariably, there is an interplay between Ujamaa philosophy and theology. So, it is permissible to state that the consonance of theology and Ujamaa makes it a possible template to critique Neo-Pentecostal capitalistic practices in Africa. We will now view African Neo-Pentecostal capitalism through the lens of Ujamaa.

\section{Contrast and analyses of Neo- Pentecostal capitalism in the eye of Ujamaa}

The followings are contrast and analyses made.

\section{Ujamaa principles are at variance with Neo- Pentecostal capitalistic exploitation of fellow humans}

Ujamaa held that if a person's religion involves human sacrifice or demands exploitation of human beings, such religion is unacceptable (Mesaki \& Malipula 2011:95). This philosophy calls for the reversal of exploitative practices like the sale of miracles and healings, manipulative fundraising, extortion of funds and material gifts such as lands, houses cars from church adherents for the expansion of the wealth of some profiteering Neo-Pentecostal leaders. In essence, practices like commercial healing as seen in Iginla's pool of Bethesda in the subsection titled 'Prophet Joshua Iginla, Sheperd Bushiri and Alpha Lukau', sales of prayers for secured virginity and extension of lifespan as seen in Funke Adejumo's fundraising style in the subsection 'Matthew Ashimolowo and Funke Adejumo', the commercialisation and deification of prosperity objects by Bishop Olowonla in the subsection titled 'Bishop Olowonla' are highly questionable.

\section{Ujamaa principle seeks freedom from financial oppression and exploitation}

Ujamaa seeks the liberation of Africans from socio-economic oppression imposed by the colonial capitalists and the 
African bourgeoises. This is opposed to the capitalists' ideologies of Neo-Pentecostal leaders as they entrench exploitation by reaping off the hard-earned but insufficient income of the adherents. This principle calls for a change from manipulative extortion to a freewill donation in the church. For example, Bushiri's extortion of R25 000 from members as a fee for the gala night as seen in the subsection 'Prophet Joshua Iginla, Sheperd Bushiri and Alpha Lukau' above is financial exploitation that needs to stop.

\section{The principle of equality demands an ideal state where moral and civic values provide the environment for the well-being of everybody}

This is contrary to the socio-morally bankrupt Neo-Pentecostal culture which allows the Church leaders to continuously increase their wealth base whilst the adherents live in abject penury. This principle in addition to the factor of sharing demands that what is gathered by the church be shared amongst all equally irrespective of position held (see Ac 4:42ff.). Thus, Ujamaa called for a communitarian approach in ministry where individualism is forbidden and the grabbing of what belongs to all by one can be abolished. Consequently, rather than a luxurious lifestyle via accumulation of mundane things as seen in subsections 'Oristejafor and Oyakhilome' and 'Bishop Olowonla', leadership principles should be built on caring for the well-being of the congregants and surrounding communities via equal sharing of resources gathered.

Additionally, worthy of note is the role of inequality and lack of sharing in our society today. When the wealth of the church and the nation is concentrated in the hands of a few religious leaders and political actors, it creates artificial poverty. It allows a few to have more than enough whilst the majority wallow in poverty. In essence, the Neo-Pentecostal leaders need to pay attention to the referral of Pillay (2017a:7) who pontificated that Calvin considered poverty a serious problem and believed that it was the Christians responsibility to address it. Pillay's point rightly agrees with Jesus's poverty eradication and stomach infrastructure programme in Matthew 14:13-21. Consequently, rather than extorting the adherents and increasing poverty, it should be the role of the African Neo-Pentecostal leaders to add value to the lives of the masses by sharing and ensuring that nobody goes to bed hungry or continuously experiences abject penury. Although it may be difficult to attend to every poverty-related issue based on population and available resources, starting somewhere, and covering a milestone will reduce poverty in Africa.

\section{Ujamaa factor of 'common ownership' contradicts the Neo-Pentecostal capitalistic practice of 'larceny and unethical conversion'}

Ujamaa contradicts the conversion of what belongs to the entire community to personal business venture of the profiteering clergies. For example, the conversion of private jets purchased for missions, and the schools built by offertory to personal family businesses are highly condemned in an African Ujamaa society. This sharing factor calls for a reversal of individual ownership of the congregation's property as seen in the subsection 'Bishop Olowonla' above. It is antithetical to privatise control of church finances and diversion of the same via money laundering business as seen in the case of Oyakhilome and Olowonla in subsections 'Oristejafor and Oyakhilome' and 'Bishop Olowonla', respectively. It also calls for accountability because what is cooperatively owned demands public accountability.

\section{Ujamaa principle of leadership provides a modicum whereby leaders are accountable to the people through effective checks and balances}

So far, the four contrasts and analyses delineated above showed that criminal conversion and larceny can be popular in Neo-Pentecostal capitalism because there are no principles of checks and balances. Concomitantly, Pillay (2017b:3) noted that leadership vacuum and lack of accountability are part of the issues identified by the South African Council of Churches in Africa. These practices are not limited to established churches, but widespread amongst the African NeoPentecostals across Africa. These leaders do not see themselves as equal with the adherents, therefore accountability is inconsequential. Ujamaa stands contrary to these practices and calls for a reversal to accountability and honesty.

\section{A fundamental factor in Nyerere's Ujamaa is Love}

Nyerere opined that love should spread beyond nuclear and extended family to the entire community because it will promote the communitarian spirit of Africa. This is contrary to Neo-Pentecostal capitalism where lack of love in the heart of Neo-Pentecostal leaders drives their passion for exploitation, manipulation and extortion. Love gives as seen in Jesus' model in John 3:16 and Nyerere's factor of love. This factor strongly calls for a change, whereby Neo-Pentecostal leaders will focus more on what to give and what not to grab from the people. Behind extortion and exploitation are greed and selfishness, whereas behind giving and sharing is love.

\section{Ujamaa stands for equal opportunity in education}

The 'education for all' modicum contradicts the unaffordability motivated by greed, social classism in some schools owned by Neo-Pentecostal churches in Africa. The subsection titled 'Bishop Olowonla' above showed that average members of Olonwona's church cannot afford church-owned schools. Ujamaa principle of equal opportunity calls for the abolition of profit-centred policies and the reduction of exorbitant fees unaffordable by most adherents.

\section{Concluding remarks}

This article revealed that African Neo-Pentecostal capitalism is nonparallel with Ujamaa as it exhibits socio-moral and socio-economic bankrupt practices. The article noted that Ujamaa philosophy is robust to address Neo-Pentecostal capitalism and provides alternative imagination to God's 
kingdom values and people-centred leadership. This alternative imagination which calls for new thinking is synonymous with the recommendation of Jerry Pillay to the body of Christ in South Africa; the Church needs to reconfigure and start something new to achieve more acceptance and impact in the society (Pillay 2017b:6). Thus, Ujamaa principles and factors are highly recommended for the transformation of any religious organisation, nation or continent. Most importantly, beyond the listed cases and leaders in this study, most if not all African Neo-Pentecostal leaders need to consider using Ujamaa factors and principles in congregational leadership. On a final note, Ujamaa principles and factors are not limited in benefit to the NeoPentecostals; the mainline churches, other religions and African political leaders can leverage these principles and factors to build an African society where the well-being of all humankind will remain a priority.

\section{Acknowledgements Competing interests}

The authors declare that they have no financial or personal relationships that may have inappropriately influenced them in writing this article.

\section{Authors' contributions}

Both authors contributed equally to the writing of this article.

\section{Ethical considerations}

This article followed all ethical standards for research without direct contact with human or animal subjects.

\section{Funding information}

This research received no specific grant from any funding agency in the public, commercial or not-for-profit sectors.

\section{Data availability}

Data sharing is not applicable to this article as no new data were created or analysed in this study.

\section{Disclaimer}

The views and opinions expressed in this article are those of the authors and do not necessarily reflect the official policy or position of any affiliated agency of the authors.

\section{References}

Chabalala, K., 2017, 'To pay for healing is not in the bible', Independent Online, viewed 15 February 2021, from https://www.iol.co.za/pretoria-news/to-pay-for-healingis-not-in-the-bible-12485934.

Charlse, M., 2019, 'Inside Pastor Iginla's "Bethsaida pool" where members pay N50 000 to have holy bath!', High Street, viewed 15 February 2021, from https:// highstreet.ng/inside-pastor-iginlas-bethsaida-pool-where-members-pay-n50000to-have-holy-bath/.
Cilliers, C., 2019, 'Alph Lukau will allegedly give you R3.5K to pretend to be in a wheelchair', The Citizen, viewed 15 February 2021, from https://citizen co.za/ news/south-africa/society/2100189/alph-lukau-will-allegedly-give-you-r3-5k-topretend-to-be-in-a-wheelchair-report/.

Daniel, O., 2021, 'Agencies of capitalism: Evaluating Pentecostal capitalism in Nigeria using African moral philosophies', PhD thesis, Faculty of Theology and Religion, University of Pretoria.

Gbadegesin, O., 2020, 'Ujamaa: Julius Nyerere on the meaning of human existence' Ultimate Reality and Meaning 17(1), 50-69. https://doi.org/10.3138/ uram.17.1.50

Giblin, M., 1992, 'Tanzania women peasants: An ethical and theological Reflection', African Ecclesial Review 34(1), 29-44.

Halverson, R., n.d., 'Richard Halverson Quotes', AZQuotes.com, Wind and Fly LTD, viewed 06 July 2021 from, https://www.azquotes.com/quote/534191.

Hart, B., 2015, 'Private jet seized in SA with $\$ 9.3 \mathrm{mln}$ might be linked to CAN President', Legit News, viewed 26 February 2021, from https://www.legit.ng/290917private-jet-seized-sa-9-3m/n-arms-smuggling-money-linked-can-presidentreport.html.

Ijeoma, L., 2018, 'Funke Adejumo: 20 videos of her asking congregation for seed money', Lailas News, viewed 20 July 2020, from https://lailasnews.com/funkeadejumo-20-videos-of-her-asking-congregation-for-seed-money/.

Italoye, I., 2019, 'Forbes richest pastors in the world', Nigerian Infopedia, viewed 21 July 2020, from https://nigerianinfopedia.com.ng/forbes-richest-pastors-inthe-world/.

Kalu, O., 2008, African Pentecostalism: An introduction, Oxford University Press, Oxford.

Listowell, J., 1965, The making of Tanganyika, House and Maxwell, London.

Maxwell, J., 2007, The 21 irrefutable laws of leadership, Thomas Nelson Inc., Nashville, TN.

Mesaki, S. \& Malipula, M., 2011, 'Julius Nyerere's influence and legacy: From a proponent of familyhood to a candidate for sainthood', International Journal of Sociology and Anthropology 3(3), 93-100, viewed 05 April 2020, from http:// www.academicjournals.org/ijsa.

Nairaland Forum, 2010, ‘Christ Embassy Pastor, Chris Oyakhilome in \$35million money laundering scam', Religion Nairaland, viewed 12 March 2015, from http:// www.Nairaland.com.

Nkafu, M.N., 1999, African vitalogy, Paulines Publications, Nairobi.

Nyerere, J.K., 1966, Freedom and unity, Oxford University Press, Dar-es-Salaam.

Nyerere, J.K., 1968b, Freedom and socialism, Oxford University Press, Dar-es-Salaam.

Odunayo, A., 2018, 'Pastor Ashimolowo tells members to make dollar donations according to their years on earth (video)', Legit, viewed 20 July 2020, from https:// www.legit.ng/1110093-pastor-ashimolowo-tells-members-dollar-donationsaccording-years-earth-video.html.

Ogar, L., 2017, 'Bishop Olowonla: Net worth, biography, profile and investments', Info Guide Nigeria, viewed 24 August 2017, from http://www.infoguidenigeria.com/ david-oyedepo.

Okosun, D.O., 2018, 'Poverty, illiteracy cum prosperity theology: A quantitative study', International Journal of Social Sciences 8(1), 83-92, viewed 25 July 2020, from https://pdfs.semanticscholar.org/784d/eaed51264bd11fdbf1e240da986e45 e25a19.pdf.

Pettinger, T.J., 2012, 'Types of capitalism', Economics Help, viewed 24 April 2015, from https://www.economicshelp.org/blog/

Pew Research Centre, 2006, 'Overview: Pentecostalism in Africa', Pew Forum, viewed 02 January 2021, from https://www.pewforum.org/2006/10/05/overviewpentecostalism-in-africa/.

Pillay, J., 2017a, 'The church as a transformation and change agent', HTS Teologiese Studies/Theological Studies 73(3), a4352. https://doi.org/10.4102/hts.v73i3.4352

Pillay, J., 2017b, 'Faith and reality: The role and contributions of the ecumenical church to the realities and development of South Africa since the advent of democracy in 1994', HTS Teologiese Studies/Theological Studies 73(4), a4519. https://doi.org/10.4102/hts.v73i4.4519

Quayesi-Amakye, J., 2016, 'A yeast in the flour: Pentecostalism as the African realisation of the gospel', Studia Historiae ecclesiasticae Unisa 42(3), 71-84. https://doi.org/10.17159/2412-4265/2016/1591

Sahara Reporters, 2012, 'Pastor Olowonla Plc', viewed 31 May 2020, from http:// saharareporters.com/2012/04/03/pastor-david-oyedepo-plc-thenewsafrica.

Salinas, J.D., 2015, 'The prosperity gospel: A critique of the way the bible is used', Lausanne Movement, pp. 1-29, viewed 12 August 2020, from https://www. lausanne.org/content/the-prosperity-gospel-a-critique-of-the-way-the-bible-isused.

The Nigerian Voice, 2014, Akume slams Oritsejafor over controversial jet, South African arms deal, viewed 06 July 2021, from https://www.thenigerianvoice.com/ news/157893/akume-slams-oritsejaforover-controversial-jet-south-africa.html.

Synan, V., 2019, 'The origins of the Pentecostal movement', The Mechanics of Faith, viewed 28 December 2019, from https://www.hopefaithprayer.com/word-offaith/origins-pentecostal-movement/. 